УДК 339.172(062)(477)»18»

DOI: 10.24919/2519-058x.6.123897

Олексій АЛТУХОВ,

orcid.org/0000-0001-7592-9488

асистент кафедри всесвітньої історії та міжнародних відносин Луганського національного університету імені Тараса Шевченка

(Україна, Старобільськ) alex.an.altukhov@gmail.com

\title{
СТАТУТИ ОДЕСЬКОЇ ТА КИЇВСЬКОЇ БІРЖ ЯК ДЖЕРЕЛО 3 ІСТОРІЇ РОЗВИТКУ БІРЖОВОЇ СПРАВИ УКРАЇНИ У ДРУГІЙ ПОЛОВИНІ ХІХ СТ.
}

У статті розглядаються окремі аспекти розвитку біржової справи в Україні у другій половині ХІХ століття. Наголос робиться на аналізі діяльності двох ключових біржсвих організацій изього періоду: Одеської та Київської бірж, на яких велися торговельні операчїі, пов'язані з ключовими галузями украӥнського господарства епохи: иукрової та зернової. В якості головних джерел були використані Статути Одеської та Київської бірж, затверджені в 60-х рр. ХІХ століття. Ці матеріали дозволили висвітлити питання, пов'язані з організачією діяльності біржових інституцій, розглянути їх структурну організацію і правила ведення комерційної діяльності, показати функції та повноваження керівних органів, зокрема Біржових комітетів і Біржових товариств.

Ключові слова: біржа, Статут, Одеська біржа, Київська біржа, джерело, Біржовий комітет, Біржова суспільство.

Oleksii ALTUKHOV, Assistant Professor of the Department of World History and International Relations, Taras Shevchenko Luhansk National University (Ukraine.Starobilsk) alex.an.altukhov@gmail.com

\section{THE STATUTES OF ODESSA AND KIEV EXCHANGES AS A SOURCE ON THE HISTORY OF DEVELOPMENT OF STOCK EXCHANGE MATTERS IN UKRAINE IN THE SECOND HALF OF THE XIX CENTURY}

The article treats of some aspects of development of stock exchange matters in Ukraine in the second half of the XIX century. The emphasis is made on the analysis of the activities of the two key stock exchange organizations of this period, namely, Odessa and Kiev exchanges, where trading operations were carried out related to the key branches of the Ukrainian economy of that era, that is - sugar and grain. The main sources have been the Statutes of Odessa and Kiev stock exchanges, approved in the 60's of the XIX century. These materials allow the author to highlight the issues concerning the organization of the activities of exchange institutions, to consider their structural organization and rules for conducting commercial activities, to show the functions and authorities of the governing bodies, in particular, the stock exchange Committees and exchange organizations.

A significant part of the articles of the Statutes highlights the functions, rights and duties of the stock exchange Committees, that is, the governing bodies of financial organizations. According to these documents, this body should act as an intermediary in case of disputes in commercial matters, supervise the exchange house, and ensure proper and legitimate trade at the stock exchange.

In addition, the stock exchange Committees entered into relations with representatives of the authorities, including the governor generals of New Russia and Bessarabia, as well as of Kiev. The Statutes regulated the procedure for the provision of various documents to state institutions, in particular, the reports to the foreign trade department, the military governor, the State Commercial Court, which were signed by two committee members.

The stock exchange committees of the largest stock exchanges of Ukraine in the period under review consisted of three or four members elected exclusively by local merchants of the first and second guilds, who were engaged in stock exchange matters. One of the members of the committee was elected by its chairman. The composition of the governing body was elected for a period of three years. If the chairman focused on the maintenance of stock exchange documentation and the office, his assistants took on the function of treasurers, carried out economic tasks, and also acted as vice-chairmen in the absence of the chairman. If necessary, the committee authorized the election of two or three deputies to carry out various assignments from the number of permanently active stock traders. 
Also, the Statutes of Kiev and Odessa stock exchanges established the sources of the institutions' revenue, which consisted of contributions for visits and dividends from the capital and property owned by the stock exchange company. Extraordinary expenses arising in the process of the institutions'activities were paid only with the consent of the stock exchange company exercising a general control over the financial activities of the exchange Committees. Every year the committee made a financial report, which was published in local provincial newspapers.

Key words: stock exchange, Statute, Odessa stock exchange, Kiev stock exchange, source, exchange Committee, stock company.

Алексей АЛТУХОВ, асистент кафедры всемирной истории и международных отношений Луганского начіонального университета шимени Тараса Шевченка (Украина, Старобельск) alex.an.altukhov@gmail.com

\section{СТАТУТЫ ОДЕССКОЙ И КИЕВСКОЙ БИРЖ КАК ИСТОЧНИК ПО ИСТОРИИ РАЗВИТИЯ БИРЖЕВОГО ДЕЛА В УКРАИНЕ ВО ВТОРОЙ ПОЛОВИНЕ ХІХ ВЕКА}

В статье рассматриваются отдельные аспекты развития биржевого дела в Украине во второй половине XIX века. Упор делается на анализе деятельности двух ключевых биржевых организаций данного периода: Одесской и Киевской бирж, на которых велись торговые операции, связанные с ключевыми отраслями украинского хозяйства данной эпохи: сахарной и зерновой. В качестве главных источников были взяты Статуты Одесской и Киевской бирж, утвержденные в 60-х г2. ХІХ века. Данные материаль позволяют осветить вопросы, связанные с организацией деятельности биржевых институций, рассмотреть их структурную организачию и правила ведения коммерческой деятельности, показать функции и полномочия руководящих органов, в частности Биржевых комитетов и Биржевых обществ.

Ключевые слова: биржа, Статут, Одесская биржа, Киевская биржа, источник, Биржевой комитет, Биржевое общество.

The formulation of the problem. Recently, the economic history of Ukraine has attracted more and more scholars. This is due to the fact that the development of an effective economic model in our country is impossible without studying historical experience in this matter. In particular, it is important to trace the development of the stock exchange matters in the Ukrainian lands during the laying of the foundations of industrial society (the nineteenth century.).

The analysis of sources and researches. An important source for solving certain aspects of this topic is the exchange Statutes, which determine the main conditions for the functioning of these financial institutions. In particular, the specificity of the stock exchanges can be examined on the basis of the official authority of the «Charter of Commerce, Factory and Factory Industry and Handicraft» (Statutes of the Trade, 1873) and «Continuation of the Code of Laws of the Russian Empire issued from January 1, 1864 to December 31, 1867» (Continuation of the legal code, 1868), in which, among other things, the Statutes of the exchange institutions of the Russian Empire, which were valid at the time of the publication of the collection, that is, in the second half of the nineteenth century, were collected. Odessa and Kiev exchanges among them, the analysis of their statutory documents will be made in this article.

The purpose of the article. On the basis of the analysis of the Statutes of Odessa and Kiev exchanges to study some aspects of the development of the stock exchange in Ukraine in the nineteenth century.

The statement of the basic material. Since the middle of the nineteenth century, the Statute of Odessa stock exchange, among other issues, established the exchange's internal organization and defined the functions and powers of the local stock exchange Committee, which was the governing body of the organization.

Firstly, let's consider the articles of the Statute, which regulated the internal order and organized the activities of Odessa stock exchange. The document states that «the exchange rates in Odessa are held twice a week: on Mondays and Fridays, in other words, at the time of dispatch of the express mail, that is, from 12 to 2 post meridiem». The only reason for the transfer of the exchange rates of Odessa stock exchange, according to its Charter, was the transfer of the days of departure of express mail. In this case, the governing body of the institution - the exchange Committee - should have asked the local authorities to publish changes in the schedule of work in the official edition of the Odessa Vestnik. The information on the change of course days was also sent to the Department of Foreign Trade of the Russian Empire. 
The following articles of the Statute regulated the rules of bidding in Odessa stock exchange. In particular, it was stressed that «the persons of all ranks, who visit Odessa stock exchange themselves or act through the authorized persons, have to pay fourteen rubles in silver annually to the exchange committee for the maintenance of the exchange building or other needs» (Trade Statutes, 1873: 326). The residents of the city and foreign consuls, who were not involved in trade, and all the visitors of the institution, who came here out of curiosity, were released from this payment.

Since the stock exchange year in Odessa began on March 1 each year, all those wishing to attend the meetings had to notify the exchange Committee in writing.

Most of the articles of the Statute are focussed on the clarification of the functions, rights and responsibilities of the exchange Committee. According to the document, this body had to take care of the «deanery» of the stock exchange, to act as an intermediary in the event of disputes over commercial matters, to supervise the exchange house, as well as to ensure «the correct and lawful trade in Odessa stock exchange» (Commercial Orders, 1873: 327 ) Also, the committee should have selected and elected reliable exchange and «ship» brokers.

In addition, the committee entered into relations with the authorities, in particular, with the Governor General of New Russia and Bessarabia (Trade Statutes, 1873: 328). The Statute regulated the procedure for submitting various documents to government agencies. In particular, reports to the Department of Foreign Trade, the Military Governor, and Odessa Commercial Court were to be signed by two members of the committee. Various written documents addressed to the Governor General of New Russia and Bessarabia were to be signed by all the members of the exchange Committee (Charter Commerce, 1873: 328). It was enough to have one signature for documents submitted to various city authorities. For the document's authorization the committee had a seal with the image of the state emblem and the inscription «The seal of Odessa stock exchange Committee» (Charter Articles, 1873: 328).

The exchange committee consisted of three members who were elected solely by the local merchants of the first guild dealing with stock exchanges. One of the three members of the committee was elected chairman. The composition of the governing body was elected for a term of three years. If the chairman was centered on the conduct of stock documentation, his assistants assumed the role of treasurers, carried out business tasks, and also acted as deputy chairmen in the event of his absence. In case of need, the committee authorized the election of two or three deputies for the execution of various orders from the number of permanent brokers in the stock exchange.

In case of disagreement with the decisions of the exchange Committee, the dissatisfied party had the right to prepare a complaint to the Commercial Council office and even to the Governor General of New Russia and Bessarabia.

In their turn, merchants - the members of the stock exchange had the right to put forth their own proposals regarding the internal structure, exchange fees, and the way of concluding transactions, submitting them to the exchange Committee for consideration. In cases of special importance, the stock merchant had the right to require from the exchange Committee to prepare a submission to the Minister of Finance with a prior review by the Governor General.

As was stated in the Statute, the highest offense was such: «The illegal brokerage that damages trade and undermines the income of stockbrokers». The function of preventing this type of abuse was assigned to the exchange Committee. In case of detecting such actions, the committee should have reported them to the commercial court. If the guilt had been approved, then the first time the lawbreaker had to pay a fine. In the case of a repeated offence, the broker with unclean hands was to be expelled from the stock exchange. If he dared to come back to the institution again, he had to be arrested for three to seven days and to pay a large fine of 300 to 600 rubles in silver (Articles of Trade, 1873: 328).

The merchant who used the services of an illegal broker in trade cases was also subjected to punishment. He was also obliged to pay a fine in favor of «the stockbrokers-veterans».

Another leading exchange institution of Ukraine in the second half of the nineteenth century was set up in Kyiv, in accordance with its own Charter, approved in November 1865.

The document noted that « Kiev stock exchange is a place for assembly for the sake of mutual relations and transactions for all traffics and industry, and for obtaining the necessary evidence for this» (Continuation of the Code of Laws, 1868, T. X1, pp., Ust. Torg., p. 88). The institution was open for 
visits every day, except weekends and holidays: Christmas, January 1, Epiphany, the Annunciation, Good Friday, Easter and Pentecost. The Statute noted that «the appointment of the time for opening and closing, exchange fees and exchange rates depends on the stock exchange community, present at the exchange «(Continuation of the Code of Laws, 1868, T. X1, p. P, Ust. Torg., p. 88).

Article 3 of the Charter regulates the rules for visiting Kyiv stock exchange. In particular, it was noted that «it is the right of a person of any class, both Russian subjects and foreigners, to visit Kyiv stock exchange and to carry out commercial transactions there within the limits of trade rights, that they hold by the law». Permanent clients of the exchange, which conducted trade operations there, had the duty to give a certain amount of money to the exchange Committee for the maintenance of the stock building set by the stock company. From the payments in favor of the institution, those visitors who worked there «were released» not for their work, but in accordance with the obligation or due to the owners who already paid for them»(Continuation of the Code of Laws, 1868, T. X1, pp. Ust. Torg., p. 88).

The Statute assigned that the exchange year in Kyiv began on March 1. Those who wanted to work at the institution during January and February, had to make a written request to the exchange Committee and to pay a certain amount of money for the maintenance of the organization. After the nominees had been approved, the nominal tickets were issued for them, which gave the right to attend the exchange meetings.

Also, the document established the procedure for foreign nationals who «came to Kyiv after the expiration of a specified term and did not contribute to the maintenance of the stock exchange through their commissions». According to the Statutory rules, they could have declared themselves to the exchange Committee at any time, after paying the stock fee. «This application must be filed before the beginning of any commercial turnover on the stock exchange» (Continuation of the Code of Laws, 1868, T. X1, pp., Ust. Torg, p. 88).

Unlike Odessa, the access to Kiev stock exchange for people who did not intend to constantly work there and merely came out curiosity was also paid. They were obliged to pay a certain amount and receive a one-time ticket.

According to the Charter, Kyiv stock exchange consisted of both local and non-local merchants of the first and second guilds who wished to be members. Such were to make, in addition to the fixed exchange fee, a voluntary contribution to the maintenance of the institution, the amount of which was set annually. Members of the stock exchange were elected by the subscription of the City Duma, which remained open until the election of its members and members of the exchange Committee. Those who did not have time to register in the subscription and had the desire to be members of Kiev stock exchange had to file a corresponding statement for the chairman of the exchange Committee.

In order to discuss topics concerning the maintenance of the exchange, the stock company held special meetings, to which all its members, who at that time was in Kiev, were invited. The chairman of the exchange Committee presided at such meetings (Continuation of the Code of Laws, 1868, T. X1, pp., Ust. Torg, p. 88). A similar meeting was also organized for the election of members of the exchange Committee. This meeting was presided over by the Governor General of Kiev.

The regular meetings of the stock company, in accordance with the Charter, were held twice a year: in January (when contracts were concluded) and in March, at the beginning of the exchange year. During the first meeting, issues related to finance were considered and the members of the exchange Committee were elected. At the second meeting, the reports of the members of the management of the institution on maintaining of trade order and on the state of trading in the previous year were made. The meeting was convened by necessity.

The issues raised at the meetings of the stock company were solved by means of direct voting and by a majority of votes. The exceptions were only the issues concerning the definition of the amount of the stock fee or the expenditure of the company's funds. In this case, the decision was made only by twothirds of the Committee's members.

In accordance with its Statute, Kyiv stock exchange was the main governing body of the institution which decisions were depended on the exchange Committee. It had the power to determine the rules of fees and to establish the rules for the conclusion of stock exchanges. 
In its turn, the function of the exchange Committee was to manage the stock exchange and the economic part. This body consisted of a chairman and three members who were elected from the representatives of Kiev stock exchange. Also, the board included a «goof broker». All of them were elected for three years during which they did not have the right to hold positions among the city authorities. Only those members of Kiev stock exchange who already had civil service positions or those who did not have a permanent representation in the city had the right to refuse the election the governing body. Members of the exchange Committee were called «Stock Offshore Companies». Their functions were distributed among them by mutual agreement. According to Article 13 of the Statute, they could not be representatives of the same firm (Continuation of the Code of Laws, 1868, T. X1, pp., Ust. Torg., P. 90).

The exchange's Committee had the right to elect two or three brokers to perform various orders. With the consent of the stock company, the chairman also hired, if necessary, an architect to supervise the stock building and make the necessary repairs; as well as a certain number of clerks for keeping records and correspondence.

The meetings of the exchange Committee were held at least once a week. In extreme cases, they were held at a time determined by the chairman. In the absence of the chairman of the committee, his place was occupied by a deputy elected by the stock exchange out of the circle of its members.

One of the main functions of the Committee was to maintain relations with «the places and persons whose promotion is necessary in matters related to the exchange and which require intervention of the management. The committee directly contacted the head of the Kiev gubernia, and in case of great need had the right to address the administration of Kiev, Podilia and Volhynia Governor General. In the latter case, the chairman of the committee was obliged to submit to the gubernia's governor the copy of the document, which was sent for the consideration by the Governor General. Appeals of the committee to the Ministry of Finance of the empire were to be imposed on the Governor General of Kiev gubernia

The Statute also emphasized that the Department of Trade and Manufactures was in charge of Kyiv stock exchange by the Ministry of Finance (Continuation of the Code of Laws, 1868, T. X1, pp., Ust. Torg., P. 90).

Committee members were obliged to keep special journals, in which their orders regarding current issues were recorded, as well as submission to various state authorities.

The decisions of the meetings of the exchange Committee were taken by a majority of votes. In case when the equal number of members voted for the decision, its adoption depended which party the chairman or his deputy would side with.

The Committee had a seal with the emblem of Kyiv and the inscription: «The Seal of Kiev Commercial Committee» (Continuation of the Code of Laws, 1868, T. X1, pp., Ust. Torg, p. 91).

The Articles of the Charter defined the main responsibilities of the stock exchange Committee, among which were the following:

1. assistance in the conclusion of exchange transactions;

2. conducting business exchange matters;

3. observing the timely and permanent receipt of income for the maintenance of the stock exchange;

4. keeping a book of income and expenses (Continuation of the Code of Laws, 1868, T. X1, pp., Ust. Torg., P. 91).

In addition, the exchange Committee was placed under the supervision of trafficking in trade rights that were legally owned by each individual. Also, the body was supposed to prevent «the illegal brokerage, which led to damage and undermined commerce on the whole» To this end, special books were issued, which included information about the individuals who were part of the stock company: the name, the surname, the firms they represented, the place of residence and rank.

The following Articles of the Charter were defined by the rights and obligations of the goof-broker, which post was appointed by members of the stock company on the submission of the committee and with the permission of the Minister of Finance. The order of his appointment, dismissal, rights and responsibilities was determined by a special instruction, the rules of which were established in accordance with the rules of St Petersburg's stock exchange. This document was approved by the Minister of Finance and was to be agreed with the Governor General of Kiev. 
As for merchants who worked in the stock exchange, they, according to the Statute, had the following rights and obligations:

1. fulfillment of all orders of the senior officers, which were presented in the form of announcements placed in the stock exchange;

2. in case of misunderstanding, the members of the stock exchange had the right to file a complaint for the exchange Committee or one of its members;

3. In case of dissatisfaction with the decision of the exchange Committee, the bidders had the right to file a complaint for the Governor General of the gubernia (Continuation of the Code of Laws, 1868, T. X1, pp., Ust. Torg., P. 91).

For the change of rules of the financial institution of Kiev, a system of penalties for those who were engaged in speculation and abuse, was established. In particular, the Statute noted that «if one of the visitors of the exchange is caught in the dissemination of false information harmful to trade, then this guilt will be punished in accordance with the «Ulozheniya o Nakazaniyah» (with the regulations on punishments), ed. 1866 «(Continuation of the Code of Laws), 1868, T. X1, pp., Ust. Torg., P. 91).

For someone who was spotted in an illegal brokerage, which damaged trade and led to a decrease in revenues of other stockbrokers, a fine was imposed, half of which was intended for the one who reported on the loss. The other half went to the aid to a stock exchange veteran, not able to deal with stockbrokers. If the culprit continued to engage in abuses and was caught up for the second time, then they were no longer allowed to operate in the stock exchange. If the exile appeared on the stock exchange in spite of the ban, he was a subject to be arrested for the term from three to seven days, and was forced to pay a fine, the amount of which ranged from 300 to 600 rubles in silver. The fine was imposed also on the merchant, who was used for the conclusion of trade agreements by the services of an illegal broker. The money received in this way went to help the veteran brokers.

The Charter of Kiev stock exchange also established the sources of income of the institution, which consisted of contributions for visits and dividends from the capital and property belonging to the running societies. Extraordinary expenses. that have arosed during the activity of the institution, were paid only with the consent of the stock company, which exercised general control over the financial activities of the exchange Committee. Each year, the committee made a financial report, which was published in local provincial newsletters (Continuation of the Code of Laws, 1868, T. X1, pp., Ust Torg., P. 91).

The conclusion. Consequently, the Statutes of Odessa and Kyiv stock exchanges, approved in the second half of the nineteenth century, made it possible to highlight the issues related to the organization of the activities of these financial institutions, to review their organizational structure and rules, and to show the functions and powers of the governing bodies. An analysis of the activities of these institutions and its results will be carried out in the oncoming scientific articles.

\section{СПИСОК ВИКОРИСТАНИХ ДЖЕРЕЛ І ЛІТЕРАТУРИ}

Продолжение свода законов, 1867 - Продолжение свода законов Российской империи изданного с 1 января 1864 по 31 Декабря 1867 года. Часть III. Статьи к X, XI, XII, XIII, XIV и XV томам свода. СПб.: Типография второго отделения собственной Е. И. В. Канцелярии, 1868. 1146 с.

Уставы, 1873 - Уставы торговый, фабричной и заводской промышленности и ремесленный. СПб.: Типографія Ретгера и Шнейдера, 1873. 917 с.

\section{REFERENCES}

Continuation of the Code, 1868 - Prodolzhenie svoda zakonov Rossijskoj imperii izdannogo s 1 janvarja 1864 po 31 Dekabrja 1867 goda. Chast' III. Stat'i k X, XI, XII, XIII, XIV i XV tomam svoda. SPb.: Tipografija vtorogo otdelenija sobstvennoj E. I. V. Kanceljarii, 1868. - 1146 s. [Continuation of the Code of laws of the Russian empire published since January 1, 1864 till December 31, 1867 year. Chapter III. Articles to X, XI, XII, XIII, XIV and XV volumes of the code]. St. Petersburg.: Printing House of the Second Department of His Imperial Majesty's Office, 1868. 1146 p. [in Russian].

Statuses, 1873 - Ustavy torgovyj, fabrichnoj i zavodskoj promyshlennosti i remeslennyj. SPb.: Tipografija Retgera i Shnejdera, 1873. - 917 s. [Statuses of trade, factory, plant and manufacture industries]. St. Petersburg.: Rutger and Schneider Printing House, 1873. 917 p. [in Russian].

Стаття надійшла до редакиії 16.02.2018 p. 